\title{
Profil Angular Cheilitis pada penderita HIVIAIDS di UPIPI RSUD Dr. Soetomo Surabaya 2014
}

\author{
Alexander Patera Nugraha*, Mintarsih Djamhari K.**, Adiastuti Endah P.**, Bagus Soebadii*, Erwin Asta Triyono**, Remita \\ Adya Prasetyo ${ }^{\star * * *}$, dan Sulistyowati Budi ${ }^{\star * * *}$ \\ *Prodi Pendidikan Dokter Gigi Fakultas Kedokteran Gigi, Universitas Airlangga, Surabaya, Jawa Timur, Indonesia \\ **Departemen IImu Penyakit Mulut, Fakultas Kedokteran Gigi, Universitas Airlangga, Surabaya, Jawa Timur, Indonesia \\ ***Departemen Fungsional Penyakit Dalam, Fakultas Kedokteran Universitas Airlangga, Rumah Sakit Umum Daerah Dr. Soetomo, \\ Surabaya, Jawa Timur, Indonesia \\ ****Departemen Fungsional Gigi dan Mulut Departemen IImu Penyakit Mulut, Rumah Sakit Umum Daerah Dr. Soetomo, Surabaya, \\ Jawa Timur, Indonesia \\ *JI. Mayjen Prof. Dr. Moestopo No. 47, Kampus A, Surabaya, Jawa Timur, Indonesia; e-mail: alexander.sandro11@gmail.com
}

\begin{abstract}
ABSTRAK
Human immunodeficiency virus (HIV) dan Acquired Immunodeficiency Syndrome (AIDS) telah menjadi masalah kesehatan dunia. Kasus HIV siap tahunnya terus meningkat sehingga membahayakan manusia selama lebih dari 20 tahun. Lesi oral terkait HIV dapat digunakan sebagai penanda status imun seseorang. Angular Cheilitis (AC) adalah salah satu dari tujuh lesi oral yang sangat terkait dengan infeksi HIV yang telah diidentifikasi dan dikalibrasi secara internasional. Tujuan penelitian ini adalah untuk mengidentifikasi AC dan hubungan dengan nilai hitung Cluster of Differentiation $4\left(\mathrm{CD}^{+}\right)$pada pasien HIVIAIDS di Unit Perawatan Penyakit Infeksi intermediet (UPIPI) RSUD Dr. Soetomo Surabaya 2014. Penelitian analitik observasional secara cross-sectional dan total sampling. Sampel terdiri dari 88 pasien HIV / AIDS yang dirawat di RSUD Dr Soetomo UPIPI Surabaya dari Juli hingga Agustus 2014. Diagnosis dari AC dilakukan secara klinis, rongga mulut subjek penelitian diperiksa oleh dokter gigi spesialis Penyakit Mulut (IPM). Nilai hitung $\mathrm{CD}^{+}$diperoleh dari rekam medis pasien. Delapan puluh delapan pasien HIV/AIDS telah diperiksa dan dijumpai 120 kasus manifestasi oral, diantaranya terdapat 31 kasus AC $(25,83 \%)$. AC ditemukan secara signifikan berkorelasi dengan penurunan jumlah sel CD4 ${ }^{+}$di bawah $200 \mathrm{sel} / \mathrm{mm}^{3}(p<-, 245)$. Analisis Risiko relatif menunjukkan bahwa pasien HIV / AIDS dengan Oral Candidiasis 7.5 kali lebih sering menderita AC. Terdapat Korelasi yang erat antara AC dan OC $(p<0,357)$. AC dapat digunakan sebagai alternatif untuk memprediksi nilai $C D 4^{+}$dan memprediksi status imun pasien yang terinfeksi HIV secara klinis.
\end{abstract}

Maj Ked Gi Ind. Juni 2015; 1(1): hal 12-20

Kata kunci: Angular Cheilitis, HIVIAIDS, CD4 ${ }^{+}$

ABSTRACT: Profile of Angular Cheilitis in HIVIAIDS Patients at UPIPI RSUD Dr. Soetomo Surabaya 2014. For over twenty years, human immunodeficiency virus (HIV) infection and acquired immunodeficiency syndrome (AIDS) have become a significant public health concern, and the epidemic continues to challenge humanity. HIV related oral lesions can be used as markers of the immune status. Angular Cheilitis (AC) which is one of the seven oral manifestations which are strongly associated with HIV Infection, has been identified and internationally calibrated. The purpose of this research is to identify the Angular Cheilitis and its association with reduced Cluster of Differentiation 4 (CD4+) count in HIVIAIDS patients at Unit Perawatan Intermediet Penyakit Infeksi (UPIPI) RSUD Dr. Soetomo Surabaya. This was an Analytic observasional research with cross-sectional and total sampling method. The samples consisted of 88 HIV/AIDS patients treated in UPIPI RSUD Dr. Soetomo Surabaya from July to August 2014. The Diagnosis of Angular Cheilitis was based on clinical appearance; the oral cavities of the research subjects were examined by dentists specialized in Oral Medicine. $C D 4+$ counts were obtained from the patient's medical record. Eighty Eight HIVIAIDS patients were examined and there were 120 cases of oral manifestation. There were 31 cases of Angular Cheilitis (25,83\%). Angular Cheilitis was found to be significantly correlated to the decrease in CD4+ cell count below 200 cells/mm3 $(P<-, 245)$. Risk Relative anaylsis concludes that HIVIAIDS patients with Candidiasis Oral 7.5 more often suffer from AC. There is a correlation between $A C$ and $O C(p<0,357)$. Angular Cheilitis may be used as an alternative to predict CD4+ count at field-based settings to diagnose the immunocompromised status of HIV-infected individuals.

Maj Ked Gi Ind. Juni 2015; 1(1): hal 12-20

Keywords: Angular Cheilitis, HIV/AIDS, CD4+

\section{PENDAHULUAN}

Acquired Immune Deficiency Syndrome (AIDS) adalah sekumpulan gejala penyakit akibat menurun atau rusaknya sistem kekebalan tubuh, dengan penyebabnya adalah Human Immunodeficiency Virus (HIV). ${ }^{1}$ Acquired Immunodeficiency Syndrome 
(AIDS) diindentifikasi sebagai penyakit baru pada tahun 1981 dan agen etiologinya adalah Human Immunodeficiency Virus (HIV) ditemukan pada tahun 1983. Dua jenis HIV yaitu HIV-1 dan HIV-2 telah diindentifikasi. HIV-1 jenis yang paling virulen dan strain patogenik. Diseluruh dunia virus yang predominan adalah HIV-1. ${ }^{2}$

HIV telah menjadi masalah kesehatan dunia, telah membahayakan kesehatan manusia selama lebih dari 20 tahun. Kasus HIV terus meningkat tiap tahun. HIV telah banyak diderita oleh seluruh penduduk dunia dan telah menjadi permasalahan kesehatan secara global. Pada tahun 1987 hingga September 2014 dijumpai penderita HIV sebanyak 150,296 penderita dan AIDS sebanyak 55,799 dengan angka kematian 9,796. Provinsi Jawa Timur masih menduduki peringkat kedua provinsi dengan penderita infeksi HIV tertinggi yaitu sebanyak 19,249 dan penderita AIDS 8,976.3.4

RSUD Dr. Soetomo merupakan Rumah Sakit Tipe A yang menjadi pusat rujukan terbesar kedua di Indonesia yang melayani Indonesia bagian Timur. Rumah Sakit ini milik Pemerintah Provinsi Jawa Timur yang melayani sektor kesehatan sejak tahun 1938. RSUD Dr. Soetomo menjadi salah satu dari tujuh Rumah Sakit yang ditunjuk oleh Kementrian Kesehatan RI sebagai Pilot Project Pelayanan dan Penanggulangan HIVIAIDS sejak tahun 2010 dipusatkan di Unit Perawatan Intermediet Penyakit Infeksi (UPIPI). ${ }^{5}$

Kesehatan rongga mulut merupakan hal yang penting dalam menilai status kesehatan sistemik seseorang, tidak terkecuali pada penderita HIV/ AIDS. ${ }^{5}$ Sekitar lebih dari $60 \%$ penderita infeksi HIV dan $90 \%$ penderita AIDS memiliki manifestasi oral. Manifestasi oral sering menunjukkan tanda klinis awal dari penyakit sistemik termasuk infeksi HIVIAIDS. ${ }^{6}$ Manifestasi oral pada infeksi HIV selain dapat digunakan untuk mengklasifikasikan dan menentukan stadium penyakit, memprediksi morbiditas dan kesehatan penderita secara umum. $^{7}$ Lesi oral terkait HIV dapat digunakan sebagai penanda status imun seseorang. Angular Cheilitis (AC) adalah salah satu dari tujuh lesi oral yang sangat terkait dengan infeksi HIV yang telah diidentifikasi dan dikalibrasi secara internasional. ${ }^{8,9}$
AC adalah kondisi keradangan yang terjadi pada salah satu atau kedua sudut mulut yang ditandai dengan adanya eritema, fissure, deskuamasi dan rasa nyeri. Lesi ini sering terjadi akibat koinfeksi Candida dan Staphylococcus aureus. AC yang terjadi pada golongan usia produktif dapat dicurigai adanya keterlibatan infeksi HIV karena AC umumnya dapat terjadi pada anakanak dan lansia, sehingga $A C$ dapat menjadi salah satu pertanda dini diagnosis penyakit HIV. . $^{10,11}$

Penelitian profil Angular Chelitis terkait dengan HIVIAIDS di beberapa wilayah di dunia penting dilakukan untuk mengetahui secara mendalam deskripsi dari epidemik HIVIAIDS dan menjadi dasar penelitian selanjutnya. Penelitian ini dilakukan untuk mengetahui profil Angular Chelitis pada penderita HIVIAIDS di UPIPI RSUD. Dr. Soetomo Surabaya tahun 2014.

\section{METODE PENELITIAN}

Pada penelitian yang digunakan metode observasional deskriptif secara cross-sectional. Sampel dipilih secara total sampling. Sampel yang digunakan adalah penderita HIVIAIDS yang dirawat di Rawat Inap Medik, Rawat Jalan (IRJ), Poli Gigi dan Mulut UPIPI RSUD Dr. Soetomo Surabaya bulan Juli-Agustus 2014 dijumpai 120 kasus pada 88 penderita HIVIAIDS yang sesuai dengan kriteria penelitian dan bersedia berpartisipasi dengan mengisi informed consent. Penelitian ini telah mendapatkan Ethical Clearance untuk menggunakan pasien RSUD Dr. Soetomo sebagai subjek penelitian. Ethical Clearance diberikan oleh Komite Etik Penelitian Kesehatan RSUD Dr Soetomo dengan nomor surat 301/Panke.KKE/ $\mathrm{VI} / 2014$ yang diberikan tanggal 20 Juni 2014.

\section{HASIL PENELITIAN}

Berdasarkan hasil penelitian yang dilakukan bulan Juli-Agustus 2014 di Unit Perawatan Intermediet Penyakit Infeksi (UPIPI) dapat diperoleh data yang berhubungan dengan terjadinya Angular Cheilitis (AC) pada penderita HIVIAIDS. 
Tabel 1. Total Sampling Penderita HIV dan non-HIV pada bulan Juli-Agustus 2014 di UPIPI

\begin{tabular}{cc}
\hline Sampel & Jumlah \\
\hline HIV+ & $88(100 \%)$ \\
HIV- & 0 \\
\hline
\end{tabular}

Tabel 2. Total Sampling penderita HIVIAIDS menderita AC saat pemeriksaan pada bulan Juli-Agustus 2014 di UPIPI

\begin{tabular}{cc}
\hline Lesi & HIV+ \\
\hline AC + & $34(38,64 \%)$ \\
AC- & $54(61,36 \%)$ \\
Total & $88(100 \%)$ \\
\hline
\end{tabular}

Tabel 3. Distribusi Jenis Kelamin penderita HIV menderita AC

\begin{tabular}{cc}
\hline Jenis Kelamin & Angular Cheilitis \\
\hline Laki-laki & $21(67,74 \%)$ \\
Perempuan & $10(32,26 \%)$ \\
Total & $31(100 \%)$ \\
\hline
\end{tabular}

Tabel 4. Distribusi Tempat perawatan penderita HIV yang menderita AC

\begin{tabular}{|c|c|c|c|}
\hline $\begin{array}{c}\text { Manifestasi } \\
\text { Oral }\end{array}$ & $\begin{array}{c}\text { Rawat } \\
\text { Inap }\end{array}$ & $\begin{array}{l}\text { Rawat } \\
\text { Jalan }\end{array}$ & Total \\
\hline $\begin{array}{l}\text { Angular } \\
\text { Cheilitis }\end{array}$ & $\begin{array}{c}28 \\
(90,32 \%)\end{array}$ & $3(9,68 \%)$ & $\begin{array}{c}31 \\
(100 \%)\end{array}$ \\
\hline
\end{tabular}

Tabel 5. Distribusi pendidikan terakhir penderita HIV yang menderita AC

\begin{tabular}{cc}
\hline Pendidikan Terakhir & Jumlah \\
\hline SD & $5(16,13 \%)$ \\
SMP & $6(19,35 \%)$ \\
SMA & $15(48,39 \%)$ \\
PTN & $2(6,45 \%)$ \\
Tdk Sekolah & $3(9,68 \%)$ \\
Total & $31(100 \%)$ \\
\hline
\end{tabular}

Tabel 6. Distribusi pekerjaan penderita HIV yang menderita AC

\begin{tabular}{cc}
\hline Perkerjaan & Jumlah \\
\hline Swasta & $11(35,48 \%)$ \\
Wiraswasta & $14(45,16 \%)$ \\
PNS & $1(3,23 \%)$ \\
Buruh & $3(9,68 \%)$ \\
Tdk kerja & $2(6,45 \%)$ \\
Total & $31(100 \%)$ \\
\hline
\end{tabular}

Tabel 7. Distribusi transmisi penularan HIV yang menderita AC

\begin{tabular}{cc}
\hline Transmisi & Jumlah \\
\hline Hubungan Sexual & $29(93,55 \%)$ \\
Narkoba Suntik & $2(6,45 \%)$ \\
Total & $31(100 \%)$ \\
\hline
\end{tabular}

Tabel 8. Distribusi orientasi sexual penderita HIV yang menderita $\mathrm{AC}$

\begin{tabular}{cc}
\hline Orientasi Sexual & Jumlah \\
\hline Heterosexual & $30(96,77 \%)$ \\
Homosexual & $1(3,23 \%)$ \\
Total & $31(100 \%)$ \\
\hline
\end{tabular}

Tabel 8. Nilai Hitung CD4+ pada 31 penderita HIVIAIDS

\begin{tabular}{lllll} 
Cd4 $^{+}$ & $\mathbf{N}$ & mean & median & St dev \\
\hline Total & 31 & 78,839 & 64,000 & 76,2977 \\
\hline
\end{tabular}

\section{PEMBAHASAN}

Human Immunodeficiency Virus (HIV) merupakan retrovirus. Retrovirus adalah virus yang mempunyai kemampuan menggunakan RNA dan DNA pejamu untuk membentuk DNA virus dengan periode inkubasi sekitar 5 sampai 10 tahun. HIV menginfeksi tubuh dengan periode inkubasi yang lama (periode laten), dan mampu menyebabkan tanda gejala penyakit yang disebut Acquired Immunodeficiency Syndrome (AIDS). Infeksi HIV merupakan infeksi virus yang menurunkan imunitas tubuh secara keseluruhan dengan signifikan dan progresif. HIV spesifik berafinitas dengan CD4+ ( $T$ helper Cells). HIV menyerang dan menganggu upaya homeostasis yang dilakukan oleh tubuh sehingga host rentan terhadap banyak infeksi oportunistik. ${ }^{1,12}$

Penderita HIVIAIDS mengalami imunodefisiensi yang menimbulkan berbagai manifestasi klinis termasuk manifestasi klinis yang muncul di dalam rongga mulut. ${ }^{5}$ Gangguan tersebut dapat menyebabkan kondisi ekosistem dalam rongga mulut menjadi tidak seimbang. Flora normal yang ada di dalam rongga mulut yang komensal menjadi patogen sehingga dapat menyebabkan munculnya infeksi oportunistik di dalam rongga mulut. ${ }^{6}$ Manifestasi oral dapat mengindikasikan 
keadaan sistemik seseorang dan merupakan tanda klinis awal yang dapat memprediksi perkembangan infeksi HIV menjadi AIDS. ${ }^{7}$

Manifestasi oral dari infeksi HIV dapat dibagi menjadi 3 kelompok: (1) lesi yang berhubungan erat dengan infeksi HIV, (2) lesi yang berhubungan jarang namun terkait dengan infeksi HIV, dan (3) Lesi yang dapat ditemukan pada infeksi HIV. ${ }^{7}$ Manifestasi oral HIVIAIDS digunakan sebagai petanda klinis yang terkait dengan diagnosis dan prognosis dari pasien yang terinfeksi HIV. ${ }^{8,9}$
Angular Cheilitis (AC) merupakan salah satu manifestasi klinis pada rongga mulut yang dapat ditemui dan berhubungan erat dengan infeksi HIV/ AIDS. Pengaruh infeksi HIV terhadap kejadian AC terbukti pada penelitian ini, yaitu dijumpai 31 kasus AC (25,83\%) (Tabel. 2), terdiri dari 28 kasus AC $(90,32 \%)$ dijumpai di rawat inap dan 3 kasus AC $(9,68 \%)$ dijumpai di rawat jalan (Tabel 4). Jumlah kasus tersebut lebih banyak daripada yang dijumpai pada penelitian $\mathrm{Hedge}^{5}$ di India tahun 2012 yakni 16 kasus (12,8\%), yang dijumpai pada penelitian

Tabel 9. Distribusi usia, jenis kelamin dan nilai hitung CD4+ pada penderita HIV yang menderita AC

\begin{tabular}{|c|c|c|c|c|c|c|c|}
\hline \multirow{2}{*}{$\begin{array}{l}\text { Age } \\
\text { (year) }\end{array}$} & \multicolumn{2}{|c|}{$\mathrm{CD4}^{+}<200 \mathrm{sel} / \mathrm{mm}^{3}$} & \multicolumn{2}{|c|}{$\mathrm{CD4}^{+} \quad 200-500 \mathrm{sel} / \mathrm{mm}^{3}$} & \multicolumn{2}{|c|}{$\mathrm{CD}^{+}>500 \mathrm{sel} / \mathrm{mm}^{3}$} & \multirow{2}{*}{ total } \\
\hline & male & female & male & Female & male & female & \\
\hline $16-25$ & 0 & 2 & 0 & 0 & 0 & 0 & $2(6,45 \%)$ \\
\hline 26-35 & 12 & 3 & & 1 & 0 & 0 & $15(48,39 \%)$ \\
\hline $36-45$ & 3 & 2 & 1 & 0 & 0 & 0 & $5(16,13 \%)$ \\
\hline $46-55$ & 2 & 2 & & 0 & 0 & 0 & $4(12,90 \%)$ \\
\hline$>55$ & 3 & 0 & & 0 & 0 & 0 & $3(9,68 \%)$ \\
\hline \multirow[t]{2}{*}{ Total } & $20(64,52 \%)$ & $\begin{array}{c}9 \\
(29,03 \%)\end{array}$ & $1(3,23 \%)$ & $\begin{array}{c}1 \\
(3,23 \%)\end{array}$ & 0 & 0 & $31(100 \%)$ \\
\hline & \multicolumn{2}{|c|}{$29(93,55 \%)$} & \multicolumn{2}{|c|}{$2(6,45 \%)$} & & & \\
\hline
\end{tabular}

Tabel 10. Uji Korelasi antara nilai hitung $\mathrm{CD} 4^{+}$dan $\mathrm{AC}, \mathrm{AC}$ dan $\mathrm{KO}, \mathrm{KO}$ dan nilai hitung $\mathrm{CD} 4^{+}$pada penderita HIV. (Nonparametric correlation analysis with Pearson test)

\begin{tabular}{ccccc} 
& & Cd4+ & AC & Candida \\
\hline \multirow{2}{*}{ Cd4+ } & Pearson Correlation & 1 &,$- 245^{*}$ &,$- 311^{* *}$ \\
& Sig. (2-tailed) & &, 022 &, 003 \\
& N & 88 & 88 & 88 \\
\multirow{2}{*}{ AC } & Pearson Correlation &,$- 245^{*}$ & 1 &, $357^{* *}$ \\
& Sig. (2-tailed) &, 022 & &, 001 \\
& Pearson Correlation & 88 & 88 & 88 \\
\multirow{2}{*}{ Candida } & Sig. (2-tailed) &,$- 311^{* *}$ &, $357^{* *}$ & 1 \\
& $\mathrm{~N}$ &, 003 &, 001 & \\
& & 88 & 88 & 88
\end{tabular}

*. Correlation is significant at the 0.05 level (2-tailed).

**. Correlation is significant at the 0.05 level (2-tailed). 
Davoodi ${ }^{14}$ di Iran tahun 2014 yakni 17 kasus (17\%). Perbedaan hasil tersebut dikarenakan perbedaan kebiasaan dan perilaku pada setiap kelompok masyarakat seperti kebiasaan menjaga kesehatan tubuh dengan makan makanan yang bergizi dan menjaga kebersihan rongga mulutnya..$^{14,15}$

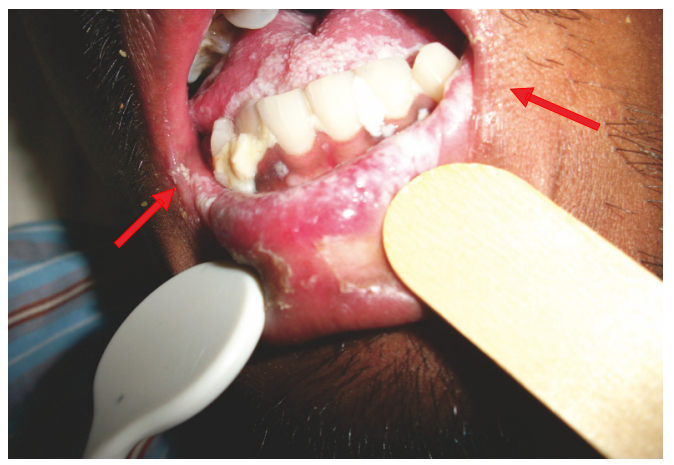

Gambar 1. Angular Cheilitis dan Oral Candidiasis

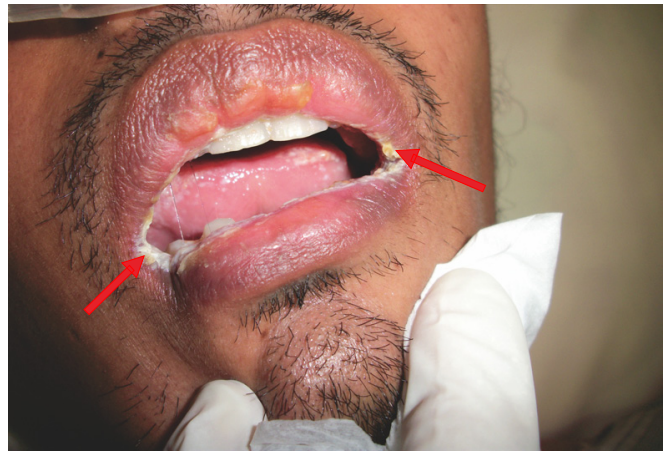

Gambar 3. Angular Cheilitis dan Oral Candidiasis satu faktor pendukung terjadinya AC..$^{13,14}$ Hasil uji Nonparametric correlation analysis with Pearson test (Tabel 10) terdapat korelasi yang signifikan di antara keduanya $(p<-, 245)$, AC ditemukan secara signifikan berkorelasi dengan penurunan jumlah sel $\mathrm{CD}^{+}$di bawah $200 \mathrm{sel} / \mathrm{mm}^{3}$. Total dari 31 pasien

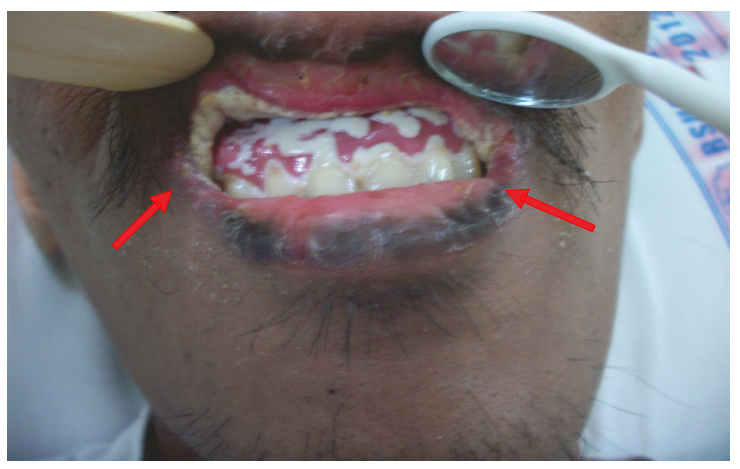

Gambar 2. Angular Cheilitis dan Oral Candidiasis

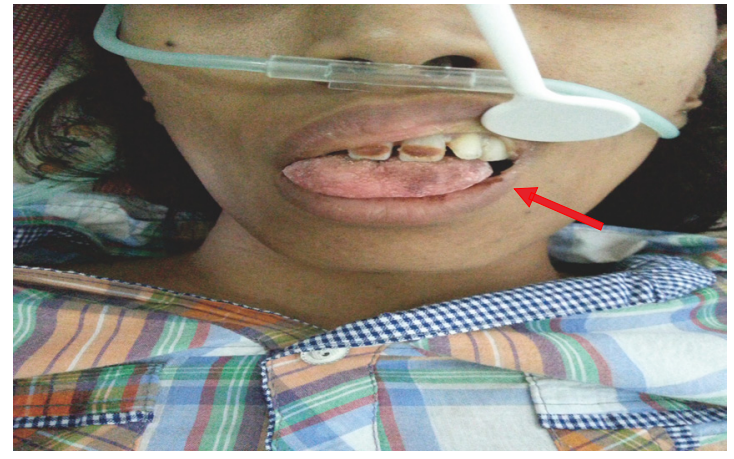

Gambar 4. Angular Cheilitis

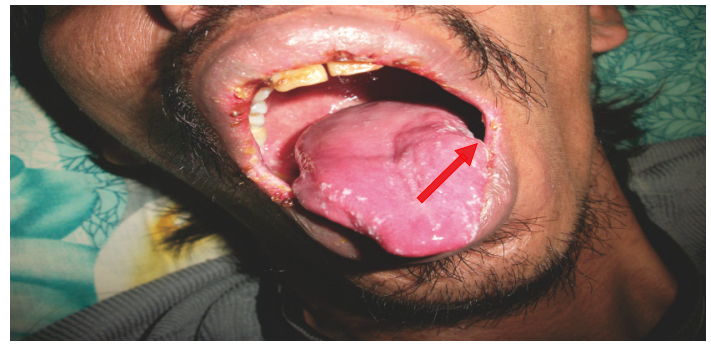

Gambar 5. Angular Cheilitis dan Oral Candidiasis

Timbulnya AC biasanya dapat ditemui pada semua tingkat keparahan penyakit HIV. Hal ini menunjukkan bahwa penurunan hitung sel limfosit $\mathrm{T} \mathrm{CD}^{+}$yang menentukan stage HIV, tidak dapat menjadi acuan utama terjadinya AC pada penderita HIVIAIDS. Meskipun demikian, tidak dapat dipungkiri bahwa penurunan sistem imun yang besar pada penderita HIVIAIDS menjadi salah
AC yang menderita HIVIAIDS dijumpai Mean CD4+ 78,839, Median 64,000, dan Std. Deviation 76,2977 (Tabel 8).

Menurut Alimonti, ${ }^{16}$ pada penderita yang terinfeksi HIV akan terjadi penurunan $\mathrm{CD}^{+}$dan peningkatan HIV-RNA viral load. HIV cenderung menyerang limfosit- $T$, karena permukaan limfosit- $T$ terdapat reseptor $\mathrm{CD} 4^{+}$yang merupakan pasangan 
ideal gp120 permukaan (surface glycoprotein 120). Limfosit-Thelper juga memiliki dua ko-reseptor (CCR5 dan CXCR4) yang membantu internalisasi virus ke dalam monosit atau makrofag. ${ }^{17}$ Viral load akan meningkat dengan cepat pada awal infeksi dan kemudian turun sampai pada suatu titik tertentu. Infeksi HIV akan semakin berlanjut sehingga viral load cenderung terus meningkat. ${ }^{18}$ Destruksi limfosit $\mathrm{T} \mathrm{CD}^{+}$akan meningkatkan viral load. Keseimbangan antara Th1 dan Th2 terlibat dalam patogenesis infeksi HIV. Sejalan dengan perjalanan penyakit akan terjadi pergeseran respon limfositThelper yang didominasi oleh Th2. Sejumlah sitokin yang diproduksi oleh Th1 akan mengalami penurunan dan sejumlah sitokin yang diproduksi oleh Th2 akan mengalami peningkatan. Sitokin yang diproduksi oleh Th1 bersifat sebagai antiapoptosis yang berusaha untuk mempertahankan jumlah limfosit-T CD4 ${ }^{+}$, sebaliknya, sitokin yang diproduksi oleh Th2 bersifat proapoptosis berusaha memacu proses apoptosis patologis sehingga terjadi penurunan kadar sel Limfosit $\mathrm{T} \mathrm{CD} 4^{+}$. Penurunan kadar sel Limfosit $\mathrm{T} \mathrm{CD}^{+}$akan meningkatkan kadar $\mathrm{CD}^{+}$bersifat sitotoksik..$^{1,19}$

Menurunnya jumlah limfosit- $T$ CD4 ${ }^{+}$menyebabkan penurunan sistem imun yang berdampak pada pertahanan individu terhadap mikroorganisme patogen menjadi lemah serta risiko infeksi oportunistik meningkat. Masuknya infeksi oportunistik menyebabkan munculnya keluhan dan gejala klinis sesuai jenis infeksi oportunistiknya. Limfosit-T CD4+ pada HIV justru yang diintervensi dan mengalami infeksi serta dirusak sehingga jumlahnya cenderung terus menurun (normal 600 sampai $1200 / \mu L)$. Sejalan dengan laju penurunan jumlah limfosit-T CD4 ${ }^{+}$, respon dari limfosit-T CD4 ${ }^{+}$ yang tersisa juga berkurang terhadap stimulasi antigen dan menjadi lebih rentan terhadap mikroorganisme yang pada kondisi normal dilindungi oleh sistem kekebalan yang diperantarai sel. Monosit-makrofag, sel dendritik dan sel NK (Natural Killer) juga memiliki ko-reseptor CCR5, dapat terinfeksi HIV tetapi tidak sampai rusak seperti yang terjadi limfosit-T CD4+, namun dapat menjadi reservoir bagi HIV sehingga meningkatkan kerentanan terhadap berbagai infeksi parasit dan infeksi intraseluler lainnya. ${ }^{1,20}$
Penderita HIVIAIDS dapat terjadi AC karena penurunan kadar $\mathrm{CD} 4^{+}$yang bersifat anti-apoptosis serta meningkatnya kadar $\mathrm{CD}^{+}$yang bersifat pro-apoptosis. $\mathrm{CD}^{+}$yang juga bersifat sitotoksik akan memicu kerusakan epitel. Kerusakan epitel tersebut memudahkan terjadinya mikrolesi yang menjadi port the entry untuk bakteri dan jamur. ${ }^{21}$

Hasil penelitian menunjukkan bahwa manifestasi oral HIVIAIDS yang paling banyak adalah OC yaitu sebanyak 65 kasus $(54,17 \%)$ yang disusul dengan AC sebanyak 31 kasus (25,83\%) (Tabel. 2). Terdapat Korelasi yang erat antara $A C$ dan OC $(p<0,357)$ (Tabel 10). Infeksi jamur Candida yang terjadi pada AC tidak lepas dengan adanya Candidiasis Oral (OC) pada mukosa rongga mulut. Pada uji analisis Risk Relative dapat terlihat bahwa penderita OC memiliki risiko sebesar 7,5 kali menderita $A C$, hal ini dikarenakan pada penderita HIVIAIDS, infeksi oportunistik dari jamur Candida yang sebenarnya bersifat komensal, lebih mudah terjadi dengan penurunan antibodi saliva yaitu slgA (secretory Immunoglobulin A) yang disebabkan oleh penurunan sel limfosit T. ${ }^{22}$ Hubungan keduanya ini terjadi karena AC, yang juga disebabkan oleh infeksi bakteri Staphylococcus aureus pada kulit, memiliki hubungan yang erat dengan jamur Candida albicans sehingga keduanya dapat menyebabkan koinfeksi yang pada akhirnya menimbulkan AC. Hal ini disebabkan Candida memiliki reseptor khusus yang sesuai pada dinding selnya dengan bakteri Staphylococcus aureus yaitu reseptor Adhesin Agglutinin-like Sequence Protein 3 (AIS3P). AIS3P adalah salah satu hyphaespecific genes. ${ }^{23}$

Angular Cheilitis (AC) sering ditemukan pada golongan usia anak dan golongan lanjut usia (geriatri). Angular Cheilitis, juga dapat ditemukan pada orang dengan usia produktif, yaitu usia 2039 tahun apabila orang tersebut dalam kondisi imunokompromais seperti salah satunya pada penderita HIVIAIDS. Hal ini menyebabkan AC dapat menjadi salah satu pertanda dini untuk membantu penegakan diagnosis dini HIV, meskipun diperlukan penegakan diagnosis lebih lanjut yang tidak hanya meliputi pemeriksaan secara klinis namun juga melalui anamnesis, riwayat penyakit, dan pemeriksaan laboratoris secara teliti. 111,14,22 $^{2}$ 
Penelitian ini menunjukkan bahwa, AC paling banyak ditemukan pada golongan usia 26-35 tahun dengan jumlah 48,39\% (Tabel 4) dan sesuai dengan penelitian Bodhade $^{13}$ yang menyatakan bahwa penderita HIVIAIDS kebanyak berusia di atas 30 . Hal ini membuktikan bahwa pada pada golongan usia produktif, AC kebanyakan dapat ditemukan pada penderita HIVIAIDS yang sistem imun tubuhnya rendah. Pada orang dengan HIVIAIDS, sistem imun tubuh yang rendah mempengaruhi fungsi dan jumlah makrofag dan neutrofil, sehingga proses fagositosis yang dapat mengeliminasi infeksi jamur dan bakteri menjadi terhambat. Akibatnya, infeksi oportunistik dari jamur Candida albicans dan bakteri Staphylococcus aureus penyebab AC, dapat lebih mudah terjadi. AC merupakan kelainan rongga mulut dengan penyebab multifaktorial. Selain disebabkan oleh koinfeksi antara jamur Candida albicans dan bakteri Staphylococcus aureus, timbulnya AC juga didukung oleh faktor lain seperti xerostomia, kekurangan nutrisi, merokok, serta perilaku menjaga kesehatan mulut (oral hygiene) yang kurang baik. ${ }^{15,16}$

Pada penelitian ini (Tabel 3) dapat dilihat mengenai prevalensi jenis kelamin penderita AC yang menderita HIVIAIDS. Jumlah penderita HIVIAIDS berjenis kelamin laki-laki sebanyak 21 $(67,74 \%)$ dan 10 penderita $(32,26 \%)$ perempuan. Penelitian di UPIPI RSUD Dr. Soetomo tahun 2011 dijumpai $69 \%$ penderita laki-laki dan $31 \%$ penderita perempuan. Perbedaan tersebut terjadi karena adanya perbedaan pola hidup, kebiasaan, dan perilaku seperti pada laki-laki lebih cenderung untuk berganti-ganti pasangan sehingga lebih berisiko untuk tertular HIVIAIDS, sedangkan penderita dengan jenis kelamin perempuan menjadi korban yang tertular HIVIAIDS dari suami yang sering berganti-ganti pasangan. ${ }^{21,23,24}$

Prevalensi transmisi penularan pada penderita $A C$ yang menderita HIVIAIDS yang paling sering dijumpai yaitu melalui transmisi hubungan seksual yaitu sebanyak 29 penderita $(93,55 \%)$ dan 2 penderita $(6,45 \%)$ tertular HIVI AIDS melalui cara jarum suntik narkoba (IDU) (Tabel 7). Penderita AC yang menderita HIV yang tertular melalui hubungan seksual yang berorientasi heteroseksual sebanyak 30 penderita $(96,77 \%)$ dan 1 penderita homoseksual (3,23\%) (Tabel 8). Penelitian Margiotta et al, ${ }^{25}$ dijumpai transmisi HIV/ AIDS melalui hubungan seksual dengan orientasi heteroseksual merupakan transmisi paling umum dan sering, oleh karena itu cukup banyak dijumpai penderita HIVIAIDS wanita. Data ini sesuai dengan data Komisi Penanggulangan AIDS tahun 2012 yaitu sebanyak 204 penderita $(53,40 \%)$ tertular melalui hubungan seksual, 161 penderita $(42,15 \%)$ karena penggunaan narkoba suntik, dan 6 penderita $(1,57 \%)$ melalui perinatal, sisanya penyebab tidak diketahui 11 penderita $(2,88 \%))^{21,26}$ Jika dilihat dari cara penularannya, proporsi penularan HIVIAIDS melalui hubungan seksual (baik heteroseksual maupun homoseksual) sangat mendominasi yaitu mencapai $60 \%$, sedangkan melalui jarum suntik sebesar $30 \%$, dan ada sebagian kecil lainnya tertular secara perinatal, transfusi darah dan melalui pajanan saat bekerja. Hasil temuan pada penelitian ini seperti fenomena gunung es dimana angka kejadian sebenarnya mungkin masih lebih tinggi daripada yang dijumpai. ${ }^{21,25,26}$

Berdasarkan pembahasan di atas dapat disimpulan bahwa profil Angular Cheilitis pada penderita HIVIAIDS di UPIPI RSUD Dr. Soetomo tahun 2014 terdiri dari 28 kasus AC (90,32\%) dijumpai dirawat inap dan 3 kasus AC (9,68\%) dijumpai dirawat jalan. Angular Cheilitis ditemukan secara signifikan berkorelasi dengan penurunan jumlah sel $\mathrm{CD}^{+}$di bawah $200 \mathrm{sel} / \mathrm{mm} 3 \quad(p<$ $-, 245)$. Analisis risiko relatif menunjukkan bahwa pasien HIVIAIDS dengan OC 7.5 kali lebih sering menderita AC. Terdapat Korelasi yang erat antara $A C$ dan $O C(p<0,357)$.

\section{DAFTAR PUSTAKA}

1. Nasronudin. HIV\&AIDS Pendekatan Biologi Molekuler, Klinis dan Sosial. Edisi 1. 2007. Airlangga University Press.Surabaya: HIm. 205-215.

2. Fanales-Belasio $E$, Raimondo $M$, Suligoi B, Butto S, HIV Virology And Pathogenetic Mechanism Of Infection: A Brief Overview. Ann 1st Super Sanita. 2010. 46(1): Pp. 5-14. 
3. Join United Nations Programme on HIVIAIDS (UNAIDS). Global Report on the Global AIDS epidemic. Journal of Epidemology. 2013 3: 5-6. From UNAIDS.org Last Update April 2014.

4. Kementrian Kesehatan RI. Direktorat Jenderal Pengendalian Penyakit dan Penyehatan Lingkungan. Pedoman nasional Tatalaksanana Klinis Infeksi HIV dan Terapi Antiretroviral pada Orang dewasa. 2014. Jakarta: HIm. 1-2

5. Unit Perawatan Intermediet Penyakit Infeksi (UPIPI). Laporan Triwulan I 2014 HIVIAIDS. 2014. RSUD Dr. Soetomo Surabaya. HIm. 1.

6. Hedge M.N, Hedge N.D, Malhotra A. Prevalence of Oral Lesion in HIV Infected Adult Population of Mangalore, Karnataka-India. 2012. Reserch Article Issue. Karnataka-India 4: Pp.1.

7. Vaseliu N, Kamiru H, Kabue M. Oral Manifestation of HIV Infection. HIV Curriculum for the Health Professional. J Stomatology. 2011. 7(6) 53-55. Available on hivdent.org Accessed on May 2th 2014.

8. Patton L.L, McKaigh R, Strauss R., Rogers D, Eron JJ Jr. Changing Prevalence Of Oral Manifestations Of Human Immune-Deficiency Virus In The Era Of Protease Inhibitor Therapy. Oral Surg Oral Med Pathol Oral Radiol Endod. 2005. 89: Pp. 299-304.

9. Moylett EH. and Shearer W.T. HIV: Clinical manifestations. J Allergy Immunol. 2007. 110: Pp.3-16.

10. Greenberg MS, Glick M, Ship JA. Burkett's Oral Medicine. 11th ed. Hamilton: BC Decker Inc; 2008. p. 81, 502.

11. Park KK, Brodell RT, Helms SE. Angular Cheilitis Part 1: Local Etiologies. Cutis. June 2011; 87: 289-295.

12. Bodhade AS, Ganvir SM, Hazarey VK. Oral manifestations of HIV infection and their correlation with CD4 count. Journal of Oral Science, Vol. 53, No. 2, 203-211, 2011 Nagpur, Maharashtra, India. Pp. 203-211.
13. Davoodi P, Hamian M, Nourbaksh $R$, Motayamel FA. Oral Manifestations Related to CD4 Lymphocyte Count in HIV-Positive Patients. Dental Research, Dental Clinics, Dental Prospect. Journal of Oral Med. 2014. 7(1): 3-5. Available from dentistry.tbzmed. ac.id/joddd. Accessed on May 2th 2014.

14. Coogan MM, Greenspan J, Challacombe S.J. Oral Lesion in Infection with Human Immunodeficiency Virus. Bulletin of the World Organization. 2005. 83: Pp.700-706.

15. Park KK, Brodell RT, Helms SE. Angular Cheilitis Part 2: Nutritional, Systemic, and Drug-Related Causes and Treatment. Cutis. July 2011; 88: 27.32.

16. Alimonti JB, Ball TB, Fowke KR. Mechanism of CD4+ T Lymphocyte cell Death in Human Immunodeficiency Virus Infection and AIDS. Journal of General Virology. 2003. 84: Pp. 1649-1661

17. Sentosa E. Measurement of CD 4 By Flowcytometry in HIV Infection. Pendidikan Berkesinambungan Patologi Klinik 2005. Departemen Patologi Klinik FK UI. Penerbit Balai UI. Jakarta: HIm. 89-96.

18. Zerhouni B, Nelson J.A, Saha K. Isolation of CD4-Independent Primary Human Immunodeficiency Virus Type 1 Isolates that are Syncytium Inducing and Acutely Cytopathic for CD8+ Lymphocytes. J Virol. 2006 78(3):pp.1243-1255.

19. Handojo I. Imunoasai untuk penyakit infeksi virus. Imunoasai terapan pada beberapa penyakit infeksi. 2005. Airlangga University Press. Surabaya: HIm. 149-162.

20. Suripatty A, Renowati E, Triyono E.A, Purnomo W. Korelasi antara Kadar TGF- $\beta$ Plasma dengan Jumlah Limfosit-T CD4+ pada Penderita Terinfeksi HIV Stadium 1. Karya Akhir SMF Patologi Klinik, FK UNAIR, RSUD. Dr. Soetomo. Surabaya. 2014: HIm. 50-55.

21. Nugraha AP, Djamhari $M$, Endah $A$, Triyono E, Prasetyo R, Budi S, Prevalensi Manifestasi Oral pada Penderita HIV AIDS di UPIPI RSUD 
Dr. Soetomo Surabaya 2014. Oral Medicine Dental Journal. Vol 6(1). 2004: HIm 03.

22. Kartono AF, Soebadi B, Radithia D. Prevalensi Angular Cheilitis pada Waria Penderita HIV/ AIDS di PERWAKOS. Oral Medicine Dental Journal Vol. 6 No. 2 July-december 2014 ; 4047

23. Peters BM, Ovchinnikova ES, Krom BP, Schlecht LM, Zhou H, Hoyer LL, Busscher HJ, Van der mei HC, Jabra-Rizk MA, Shirtliff ME. Staphylococcus Aureus Adherence to Candida Albicans Hyphae is Mediated By The Hyphal Adhesin ALS3P. Microbiology 2012; 158: $2982-2984$
24. Hartanto B, Hendarti HT, Soebadi B. 2011. Prevalensi Lesi Oral Yang Tekait Erat dengan HIV pada Penderita HIVIAIDS di UPIPI RSUD Dr. Soetomo Surabaya. Oral Medicine Dental Journal. 3(1): HIm 01.

25 Komisi Penanggulangan AIDS Indonesia. Situasi HIV \& AIDS di Indonesia. KPAI Press. 2010. Jakarta: HIm. 2.

26. Nasronudin, Susilawati Y, Atika. Prevalensi Infeksi HIVIAIDS di Surabaya Indonesia. Airlangga Press. 2010 Surabaya: HIm. 17-18. 